\title{
BIOLOGICAL STUDIES ON THE STORED GRAIN MITE, CARPOGLYPHUS LACTIS (LINNE) (ACARI: ASTIGMATA:CARPOGLYPHIDAE)
}

\author{
TAHA, H. A. ${ }^{1}$, HANNAA I. MAHMOUD ${ }^{2}$, M.I. HASSAN ${ }^{2}$, \\ NAHED R. OMAR ${ }^{2}$ and HEBA M. NASR ${ }^{1}$
}

1- Plant Protection Research Institute, Agriculture Research Centre, Dokki, Giza, Egypt.

2- Faculty of science, Al- Azhar University, Nasr City, Cairo, Egypt.

(Manuscript received 3 February 2018)

\begin{abstract}

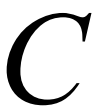
arpoglyphus lactis (Linne.) was extracted from stored grains; wheat, maize and rice; samples were collected from granary stores of Dakhlyia Governorate. In this study experiments were conducted under laboratory conditions at $25 \pm 1^{\circ} \mathrm{C}$ and $65 \pm 5$ R.H. to study the effect of dry yeast granules, crushed wheat, crushed rice as a kind of food on biological aspects, fecundity and life table parameters, of the grain mite, $C$. lactis. The obtained data showed that the ability of mite $C$. lactis to feed and develop on the above mentioned diets as a sole food sources. The average of total immature stages lasted (13.4 \&11.6), (16.5 \&15.1) and (20.0 \&18.6) days for female and male reared on the same diets, respectively. Female longevity durated 15.1, 18.5 and 19.5 days, while male adulthood averaged 19.3, 24.8 and 25.8 days, when mite fed on the above mentioned diets. Female oviposition period stayed 11.3, 12.9 and 13.6 days and the average number of deposited eggs/female was136.8, 113.9 and 70.5 eggs with a daily mean $12.1,8.8$ and 5.2 eggs on the same tested diets. The life table parameters of $C$. lactis were affected by different types of food whereas, the mean generation ( $T$ ) was $20.7,22.8$ and 28.8 , while the intrinsic rate of natural increase $(\mathrm{rm})$ values were $0.39,0.32$ and 0.24 when mite fed on the same tested diets at the same pattern.
\end{abstract}

\section{INTRODUCTION}

A large number of mites are known to infest a variety of stored products throughout the world. Their distribution pattern is, however, not constant everywhere, which varies according to the climate. They are either free living (graminivorous, fungivorous and saprophagus), parasitic and predatory on the other mites or immature stages of insects. Mites associated with stored products are great economic importance, which cause serious variable degrees of damage; not only they can consume large amount of stored products, but also contaminate food with their bodies and extractions (Taha, 1985).

The mite-population in the stored products may markedly increase, making it unsuitable for human and domestic animals consumption. Many of these mite species are also capable of infesting seeds, biscuit, bulbs, cheeses, tobacco and some legumes and others. The present work aims to study the effect of different kinds of 
food on biological developmental stages, fecundity and life table parameters of the grain mite Carpoglyphus lactis (Linne.).

\section{MATERIAL AND METHODS}

Samples of stored grains; wheat, maize and rice were collected from granary stors at Dakhlyia Governorate. In this study experiments were conducted at $25 \pm 1^{\circ} \mathrm{C}$ and $65 \pm 5$ R.H. to study the effect of different kinds of food; dry yeast, crushed wheat and crushed rice on biological aspects, fecundity and life table parameters of the grain mite, Carpoglyphus lactis. For preparing the pure culture of mite species, adult female and male were placed together in rearing cells, supplied with dry yeast granules, after female deposited eggs, formed the nucleus of the pure culture.

\section{Rearing cells:-}

Mites were reared as individuals using small hemispherical of $1 / 2$ inch in diameter and less than $1 / 4$ inch in depth. Bottom of each cell was covered with mixed of plaster of Paris and charcoal, and the top of each cell covered with small slide glass.

\section{Biological studies:-}

Eggs of $C$. lactis were incubated until hatching. The newly hatched larvae were reared singly in rearing cell and fed during its life span on one of the tested diets. In all cases, number of surviving $C$. lactis, the duration of each stage in days and egg product were assessed twice daily. Life table parameters were calculated according to Birch (1948) using the Basic Computer program of Abou-Setta et al. (1986).

\section{RESULT AND DISCUSSION}

\section{Habitat and behaviour: -}

Laboratory observation showed that only copulated females laid eggs, while uncopulated females did not oviposit as long as they remained unmated. The mite $C$. lactis (L.) developed on dry yeast granules, crushed wheat and crushed rice, the mite individuals passed through a larval and two nymphal stages before reaching adult stage. This mite species was creamy in color and its legs were slightly brownish.

\section{Matting : -}

The male could be detected, which nymphs will moult into adult female and mount them as soon as the female emerge. The male attached to the female dorsum (in which the opithosome of both are in the same direction) holding on with sucteers on its hind legs and near it anus. The aedeagus was extruded bent backward between the male's hind legs and inserted into the pore-like posterior opening of the female's reproductive tract, during that the female could move, but slow movement. Copulation took about 15 minutes after that male moved far away from the female. 


\section{Hatching : -}

The newly deposited eggs were oval in shape and white in color, which change to transparent just before hatching. Eggs were laid singly or in a small groups and attached to the substrate from one end in corners of the rearing cells. During hatching, the shell ruptured through transversal slit from which the larva crawled outside within about $5-10$ minutes.

\section{Moulting : -}

Every immature stage of $C$. lactis entered quiescent stage in which it seeked a dry corner of the rearing cell, ceased feeding and stopped moving completely. The body swelled and enlarged which made the cuticle highly stretched before moulting, the interior part of body became translucent, then the cuticle is ruptured a long transversal line and the new stage crawled forward and coming out. Newly emerged individual remained inactive beside the old exuvium for a short period.

\section{Biological aspects: \\ Incubation period:}

Mean duration of eggs stage of $C$. lactis females lasted $3.29,3.47$ and 4.0 days for both females and males when the indivduals fed on dry yeast, crushed wheat and crushed rice, respectively, Table (1).On the other hand, the incubation period of male indivduals as shown in Table (2) durated 3.22, 3.51 and 3.71 days when fed on same diets, respectively

\section{Larval stage.}

All larvae were observed to feed before developing to protonymph; as shown in Tables (1\&2) and Figs (1\&2) data cleared that the active and quiescent larvae, durated (3.5\&1.0), (3.5\&1.58) and (5.25\&1.63) days for female, while, for male lasted (2.4\&0.89), (3.1\&1.2) and (4.79\&1.29) days, when mite fed on dry yeast granules, crushed wheat and crushed rice, respectively.

\section{Nymphal stages:}

The grain mite, $C$. lactis have two nymphal stages before reaching adulthood. The obtained data in Table (1) indicated that the protonymphal stages of female indivduals lasted 3.52, 4.05 and 5.06 days for active stat, as it changed to recorded $1.19,1.42$ and 1.56 days in case of quiescent stat for female indivduals. The tabulated data in Table (2) showed that the male protonymphal stage of active indivduals took $3.11,3.73$ and 4.56 days changed to $1.11,1.27$ and 1.43 days for quiescent members at the same conditions, respectively. However, the tritonymphal stages of $C$. lactis differed according to the kind of introduced food, as it lasted 33.3, 4.47 and 5.63 days for female active stages, Table (1), and durated 1.33, 1.42 and 1.69 days for the quiescent individuals. The data in Table (2) indicated that the male 
tritonymphal active stage averaged 3.0, 4.45 and 4.93 days, as it shorted to recorded $1.0,1.36$ and 1.5 days for quiescent members when fed on dry yeast, crushed wheat and crushed rice, respectively.

\section{Total immature stages:}

Female and male immature stages lasted (13.4\&11.56), (16.5\&15.1) and (20.8\&18.57) days, when they fed on the lasted diets at the same pattern. Data showed that the male reached adult stage before female (Tables $1 \& 2$ and Figs.1\&2).

\section{Life cycle:}

Female indivduals of $C$. lactis lived longer than male under test conductions, whereas, female life cycle lasted 16.71, 19.95 and 24.81 days for females, Table (1) and $14.78,18.55$ and 22.29 days for male individuals, when the mite fed on dry yeast, crushed wheat and crushed rice, respectively, Table (2). These results coincided with El-Naggar et al. (1989), Mathur and Dalal (1985), Taha et al. (2002a) and Taha et al. (2002b).

Table 1 . Duration of different stages of Carpoglyphus lactis female when fed on different food sources at $25^{\circ} \mathrm{C} \pm 2^{\circ} \mathrm{C}$ and $65 \% \pm 5 \%$.H.

\begin{tabular}{|c|c|c|c|c|c|}
\hline & Dry yeast & Crushed wheat & Crushed rice & \multirow{2}{*}{$\begin{array}{r}\text { L.S.D } \\
0.35\end{array}$} \\
\hline Incubation p & & $\begin{array}{l}3.29 \pm 0.46 \\
b\end{array}$ & $3.47 \pm 0.48 b$ & $4.00 \pm 0.42 \quad a$ & \\
\hline \multirow[t]{2}{*}{ Larva } & $\mathbf{A}$ & $\begin{array}{l}3.05 \pm 0.59 \\
c\end{array}$ & $3.53 \pm 0.61 b$ & $5.25 \pm 0.94 \quad a$ & 0.43 \\
\hline & $\mathbf{Q}$ & $\begin{array}{l}1.00 \pm 0.00 \\
b\end{array}$ & $1.58 \pm 0.49$ a & $\begin{array}{l}1.63 \pm 0.43 \\
a\end{array}$ & 0.31 \\
\hline \multirow[t]{2}{*}{ Protonymph } & AA & $\begin{array}{l}3.52 \pm 0.51 \\
c\end{array}$ & $4.05 \pm 0.71 b$ & $5.06 \pm 0.74 \quad a$ & 0.49 \\
\hline & $\mathbf{Q}$ & $\begin{array}{l}1.19 \pm 0.40 \\
b\end{array}$ & $1.42 \pm 0.47 \mathrm{a}$ & $1.56 \pm 0.44$ a & 0.36 \\
\hline \multirow{2}{*}{ Tritonymph } & $\mathbf{A}$ & $3.33 \pm 0.66$ & $4.47 \pm 0.82 b$ & $5.63 \pm 0.86 a$ & 0.55 \\
\hline & $\mathbf{Q}$ & $1.33 \pm 0.48$ & $1.42 \pm 0.48$ a & $1.69 \pm 0.44$ a & 0.38 \\
\hline \multicolumn{2}{|c|}{ Total immature } & $13.43 \pm 0.93 \mathrm{c}$ & $16.47 \pm 1.80 \mathrm{~b}$ & $20.81 \pm 2.19 a$ & 0.81 \\
\hline \multicolumn{2}{|l|}{ Life cycle } & $16.71 \pm 0.96 \mathrm{c}$ & $19.95 \pm 1.87 b$ & $24.81 \pm 2.39 a$ & 0.79 \\
\hline \multicolumn{2}{|c|}{ Generation period } & $18.60 \pm 0.84 \mathrm{C}$ & $\begin{array}{ccc}22.50 & \pm .82 \quad b \\
0 . & \\
\end{array}$ & $28.20 \pm 1.03 \mathrm{a}$ & 1.13 \\
\hline \multicolumn{2}{|l|}{ Longevity } & $15.10 \pm 3.57 \mathrm{a}$ & $18.50 \pm 2.42 \mathrm{a}$ & $19.10 \pm 6.38$ a & 5.50 \\
\hline \multicolumn{2}{|l|}{ Life span } & $32.00 \pm 3.53 \mathrm{c}$ & $38.40 \pm 2.34 b$ & $45.60 \pm 2.17$ a & 3.33 \\
\hline
\end{tabular}

$\mathbf{A}=$ Active stage

$\mathbf{Q}=$ Quiescent stage

L.S.D = Least significant different at 0.01 
Fig. 1 . Duration of different stages of Carpoglyphus lactis when females fed on different food sources at $25^{\circ} \mathrm{C} \pm 2^{\circ} \mathrm{C}$ and $65 \% \pm 5 \%$ R.H.

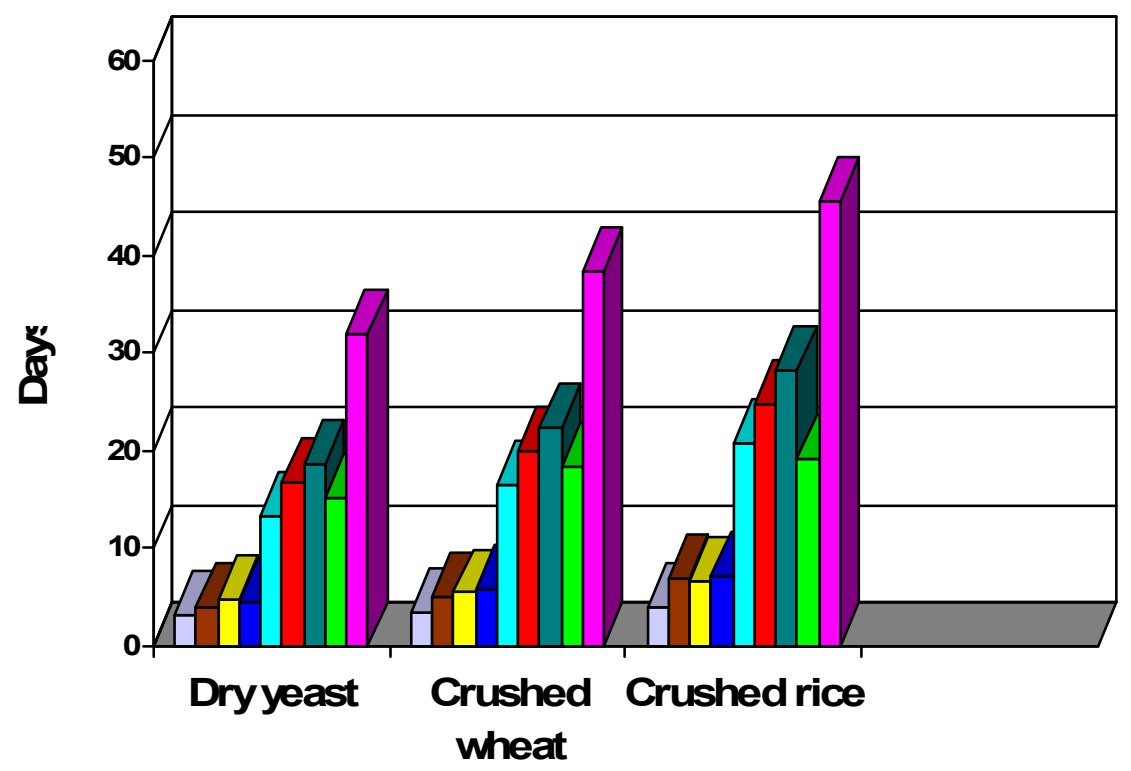

$\begin{array}{lll}\square \text { Egg } & \square \text { Lanva } & \square \text { Protonymph } \\ \square \text { Deutonymph } & \square \text { Total immature } & \square \text { Life cycle } \\ \square \text { Generation period } & \square \text { Longivity } & \square \text { Life span }\end{array}$



CARPOGLYPHUS LACTIS (LINNE) (ACARI: ASTIGMATA:CARPOGLYPHIDAE)

Table 2 . Duration of different stages of Carpoglyphus lactis male when fed on different food sources at $25^{\circ} \mathrm{C} \pm 2^{\circ} \mathrm{C}$ and $65 \% \pm 5 \%$.H.

\begin{tabular}{|c|c|c|c|c|c|}
\hline \multicolumn{2}{|l|}{ Stage } & Dry yeast & Crushed wheat & Crushed rice & L.S.D \\
\hline \multicolumn{2}{|c|}{ Incubation period } & $3.22 \pm 0.35 b$ & $3.51 \pm 0.41 \quad a$ & $3.71 \pm 0.47 \quad a$ & 0.44 \\
\hline \multirow{2}{*}{ Larva } & A & $2.44 \pm 0.41 \quad c$ & $3.09 \pm 0.36 b$ & $4.79 \pm 0.58 \quad a$ & 0.49 \\
\hline & $\mathbf{Q}$ & $0.89 \pm 0.41 \mathrm{c}$ & $1.18 \pm 0.58 \quad b$ & $1.29 \pm 0.47$ a a & 0.36 \\
\hline \multirow{2}{*}{ Protonymph } & AA & $3.11 \pm 0.26 \mathrm{c}$ & $3.73 \pm 0.35 b$ & $4.57 \pm 0.76 a$ & 0.58 \\
\hline & $\mathbf{Q}$ & $1.11 \pm 0.26 \quad a$ & $1.27 \pm 0.43 \quad a$ & $1.43 \pm 0.51 \quad a$ & 0.42 \\
\hline \multirow{2}{*}{ Tritonymph } & A & $3.00 \pm 0.00 \mathrm{c}$ & $4.45 \pm 0.41 b$ & $4.93 \pm 0.41 \quad a$ & 0.39 \\
\hline & $\mathbf{Q}$ & $1.00 \pm 0.00 b$ & $1.36 \pm 0.36 \quad a$ & $1.57 \pm 0.51 \quad a$ & 0.40 \\
\hline \multicolumn{2}{|c|}{ Total immature } & $11.56 \pm 0.46 \mathrm{c}$ & $15.09 \pm 0.36 \mathrm{~b}$ & $18.57 \pm 1.02 \quad a$ & 0.75 \\
\hline \multicolumn{2}{|l|}{ Life cycle } & $14.78 \pm 0.39 c$ & $18.55 \pm 0.36 \quad b$ & $22.29 \pm 0.83 \quad a$ & 0.69 \\
\hline \multicolumn{2}{|l|}{ Longevity } & $19.33 \pm 8.94 a$ & $24.83 \pm 8.13 \quad a$ & $25.83 \pm 3.66 \quad a$ & 12.40 \\
\hline \multicolumn{2}{|l|}{ Life span } & $34.00 \pm 8.81 b$ & $43.16 \pm 8.23 \quad a$ & $48.00 \pm 4.38 \quad a$ & 12.60 \\
\hline
\end{tabular}

$\mathbf{A}=$ Active stage

$\mathbf{Q}=$ Quiescent stage

L.S.D = Least significant different at 0.01 
Fig. 2 . Duration of different stages of Carpoglyphus lactis when males fed on different food sources at $25^{\circ} \mathrm{C} \pm 2^{\circ} \mathrm{C}$ and $65 \% \pm 5 \%$ R.H.

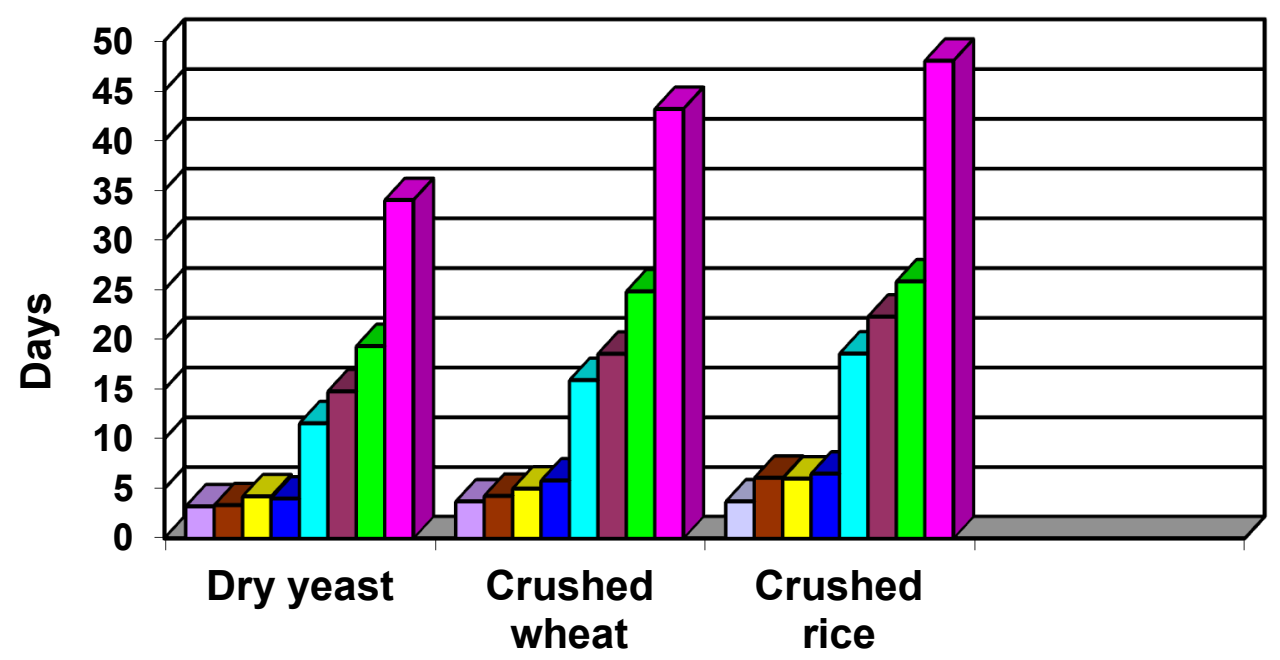

\begin{tabular}{|lll|}
\hline$\square$ Egg & $\square$ Larva & $\square$ Protonymph \\
$\square$ Tritonymph & $\square$ Total immature & $\square$ Life cycle \\
$\square$ Longevity & $\square$ Life span & \\
\hline
\end{tabular}

\section{Generation period:}

The generation period was significantly affected by different kinds of food, whereas, female generation period lasted 18.6, 22.5 and 28.2 days, when mites fed on dry yeast granules, crushed wheat and crushed rice, respectively.

\section{Longevity:}

As shown in obtained data in Table (3), the female pre-oviposition, oviposition and post-oviposition periods stayed (1.7, 11.3 \&2.1); (2.6, 12.9 \&3.2) and (3.5, 13.6 \&3.8) days, when it fed on the above mentioned diets, respectively. The oviposition period was completed in the shortest duration when fed on dry yeast granules.

These results agreement with Sinha \&Wallace (1977), Maurya \& Jamil (1982), Taha (1985), El-Naggar et al. (1989), Shreef \& Fawzy (2001) and Taha et al. (2002a \&b).

\section{Fecundity:}

Data tabulated in Table (3) cleared that female fecundity significantly increased the number of deposited eggs, which giving average of 136.8 eggs, with a 
daily rate of 12.1 eggs, when fed on dry yeast granules, compared with 70.5 eggs, with a daily rate 5.2 eggs on crushed rice. .

\section{Sex ratio:}

The tabulated data in Table (3) showed that the female percentage of the total population ranged between 55.0 and $70 \%$ these values will be considered later in the calculation of the life table parameter.

\section{Life span:}

The obtained data in Tables ( 1 \& 2 ) showed that the male adulthood was longer than female, therefore, female and male life span lasted (32.0\&34.0), (38.4 \& 43.16) and (45.6 \&48.00) days, when mites fed on the tested diets at the same pattern, respectively..

Table 3. Adult female longevity and fecundity of Carpoglyphus lactis when fed on different food sources at $25^{\circ} \mathrm{C} \pm 2{ }^{\circ} \mathrm{C}$ and $65 \% \pm 5 \%$ R.H.

\begin{tabular}{|c|c|c|c|c|c|c|c|}
\hline \multirow{2}{*}{ Diet } & \multicolumn{3}{|c|}{ Average duration (days) } & \multirow{2}{*}{$\begin{array}{l}\text { Longevity } \\
\text { (days ) }\end{array}$} & \multicolumn{2}{|c|}{ Fecundity } & \multirow{2}{*}{$\begin{array}{c}\text { Sex ratio } \\
\text { ( } \% \\
\text { females } \\
\text { /total) }\end{array}$} \\
\hline & $\begin{array}{c}\text { Preoviposition } \\
\text { period }\end{array}$ & Oviposition period & $\begin{array}{c}\text { Post oviposition } \\
\text { period }\end{array}$ & & Egg/female & $\begin{array}{l}\text { Daily } \\
\text { rate }\end{array}$ & \\
\hline Dry yeast & $1.70 \pm 0.48 c$ & $11.30 \pm 2.98 \quad a$ & $2.10 \pm 1.52 b$ & $15.10 \pm 3.57 \mathrm{a}$ & $136.80 \pm 43.52 a$ & 12.1 & $70 \%$ \\
\hline $\begin{array}{l}\text { Crushed } \\
\text { wheat }\end{array}$ & $2.60 \pm 0.52 b$ & $12.90 \pm 1.94 \mathrm{a}$ & $3.20 \pm 0.55 a$ & $18.50 \pm 2.42 \mathrm{a}$ & $113.90 \pm 14.58 \mathrm{a}$ & 8.83 & $65 \%$ \\
\hline Crushed rice & $3.50 \pm 0.53$ & $13.60 \pm 2.22 \mathrm{a}$ & $3.80 \pm 0.79 a$ & $19.10 \pm 6.38 \mathrm{a}$ & $70.50 \pm 5.48 b$ & 5.22 & $55 \%$ \\
\hline L.S.D & 0.63 & 2.99 & 1.31 & 5.50 & 32.47 & ............ & $\ldots \ldots \ldots$ \\
\hline
\end{tabular}

L.S.D = Least significant different at 0.01

The difference between data of similar letter are non-significant

The difference between data of different letter $(a, b$ \& $c)$ are significant. 
Fig. 3 . Adult female longevity and fecundity of Carpoglyphus lactis when females fed on different food sources at $25^{\circ} \mathrm{C} \pm 2^{\circ} \mathrm{C}$ and $65 \% \pm 5$ \% R.H.

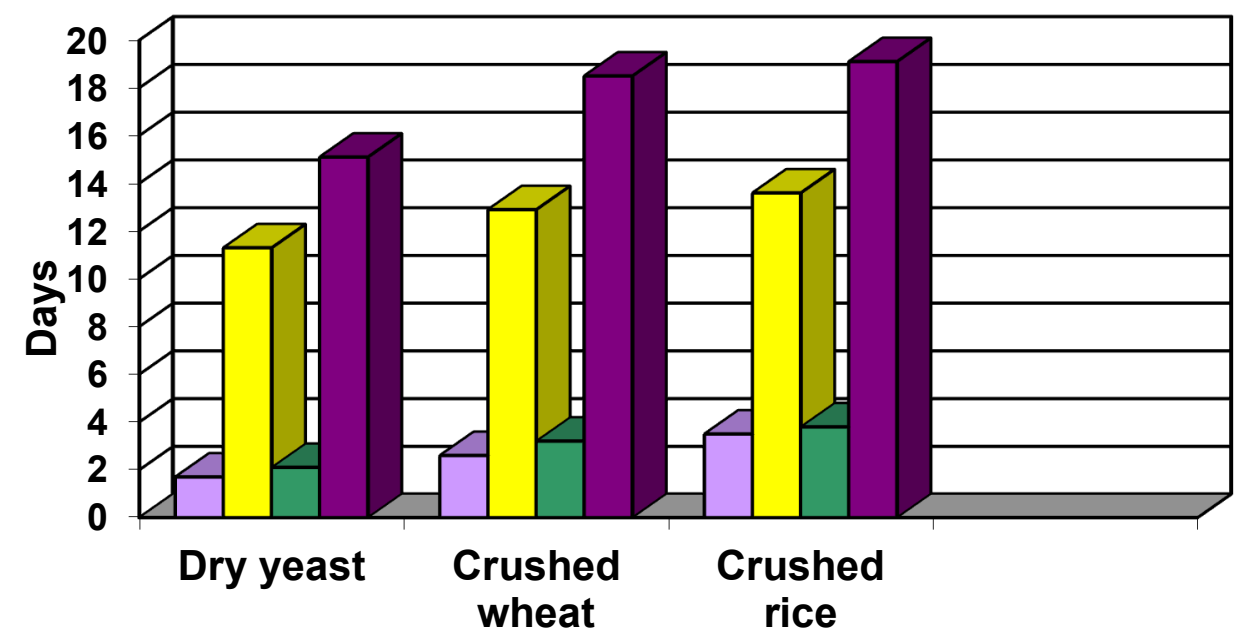

\section{$\square$ Preoviposition period $\quad \square$ Oviposition period $\square$ Post oviposition period $\quad$ Longevity}

\section{Life table parameters:}

Generation time of the grain mite, C. lactis (egg to egg) at $25^{\circ} \mathrm{C}$ and $65 \%$ R.H. was affected by diets (Table, 4). The dry yeast granules provided the shortest mean generation time ( 23.03 ) days, while, the longest mean generation time occurred with crushed rice (32.67) days. The net reproduction rate $\left(R_{0}\right)$, which is a product of mean total fecundity, survival rate and sex ratio, followed the same pattern as mean total fecundity. The highest $\left(R_{0}\right)$ value of 72.77 expected females

Table 4 . Effect of different food sources on life table parameters of Carpoglyphus lactis at $25^{\circ} \mathrm{C} \pm 2^{\circ} \mathrm{C}$ and $65 \% \pm 5 \%$ R.H.

\begin{tabular}{|c|c|c|c|}
\hline Parameters & Dry yeast & Crushed wheat & Crushed rice \\
\hline Net reproduction rate $\quad\left(R_{0}\right)$ & 72.77 & 51.46 & 24.04 \\
\hline Mean generation time $\quad(\mathrm{T})$ & 23.03 & 27.07 & 32.67 \\
\hline Intrinsic rate of increase $\left(\mathrm{r}_{\mathrm{m}}\right)$ & 0.39 & 0.32 & 0.24 \\
\hline Finite rate of increase $\left(\exp _{\mathrm{rm}}\right)$ & 1.47 & 1.37 & 1.26 \\
\hline ( \% female / total ) & $70 \%$ & $65 \%$ & $55 \%$ \\
\hline Fraction of eggs reaching maturity & 0.76 & 0.70 & 0.62 \\
\hline
\end{tabular}


per female was obtained with a diet of dry yeast, while, the lowest $\left(R_{0}\right)$ value of 24.04 expected females per female, when individuals fed on upon crushed rice. The finite rate of increase (exp.rm) values was affected by the obtained $(\mathrm{rm})$ values were 1.47, 1.37 and 1.26 when mites fed on the above mentioned diets (Table, 4).

The fraction of eggs reaching maturity (\%) recorded $76 \%, 70 \%$ and $62 \%$ when mites fed on the above mentioned diets. These results agree with Taha et al. (2002a) and Taha et al . (2009).

\section{REFRANCES}

1. Abou - Setta, M.M.;R.W. Sorrel and C.C. Childers. 1986. Life 48 : ABASIC computer program to calculate life table parameters for an insect or mite species Florida Entomol. 69 (4) : 690-697.

2. Birch, L. C. 1948. The intrinsic rate of natural increase of an insect population. J. Animal Ecol., 17:15-26.

3. El-Naggar, M.E.; H.E. Lokma and H.A. Taha. 1989. Biological studies on Rhizoglyphus ismaili (Astigmata : Acaridae) and effect of type food on duration and fecundity. Bull. Zool. Soc. Egypt, (38) : 81-86.

4. Mathour, S. and M. Dalal. 1985. Influence of food quality on the development and growth of the acarid mite, Suidasia nesbiti (Acari: Acaridae). Prog. In Acarology, 2 : 231-239.

5. Shreef, G.M. and Fawzy, M.M. 2001. Some biological observations on Grammolichus aegyptiacus $\mathrm{n}$. sp. With description of adult and immature stages (Acari: Acarididae: Glycyphagidae). Egypt. J. Agric. Res.,79(4): 1305-1316.

6. Sinha, R.N. and H.A. Wallace. 1977. Storage stability of farm stored rape-seed and barley. Can. J. Plant Sci., 5: 351-365.

7. Taha, H.A. 1985. Morphological and biological studies on some mites associated with stored products. Ph. D. Thesis, Fac. of Agric., Al-Azhar Univ., 159 pp.

8. Taha, H.A.; K.A. Abou- El-Ela,; Kawther and El-Sandy, A. Mariam. (2002a): Effect of food and temperature on developmental stages and fecundity of the grain mite, Dermatophagoides farinae Hughes (Acari: Acarididae: Pyroglyphidae). Egypt. J. Agric. Res.,82 (3): 1121-1126.

9. Taha, H.A.; K.A. Abou- El-Ela,; Kawther, Abou-Setta, M.M. and El-Sandy, A. Mariam (2002b): $2^{\text {nd }}$ International Conference, plant protection, Research Institute, Cairo, Egypt, 21-24 Dec.

10. Taha, H.A.; Mahmoud, Hanaa; Hassan, M.I.; Omar, Nahed R. and Heba, M. Nasr 2009. Effect of different food types, on the biology, fecundity and life table parameters of the stored grain mite, Gohieria fusca (Oud.) ( Acari: Astigmata: Lapidophoridae). Egypt. J. Agric. Res. (in press). 


\section{در اسات بيولوجية علي حلم الحبوب المخزونة CARPOGLYPHUS LACTIS (LINNE) (ACARI: ASTIGMATA : CARPOGLYPHIDAE)}

حسن علي أحمد طه 1 - هناء ابراهيم محمود 2 - مصطفي ابراهيم حسن 2

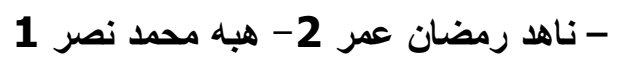
2- 1-معهد بحوث وقاية النباتات - مركز البحوث الزراعية - الدقي الجيزة - مصر الحيوان - كلية العلوم (فرع البنات) - جامعة الأزهر - مدينة نصر - القاهرة

تم استخلاص حلم الحبوب المخزونة C. lactis من حبوب القمح والذرة الثامية والأرز حيث جمعت العينات من شون الغلال بمحافظة الدقهلية. أجريت دراسة معطلية عند درجة حرارة 25

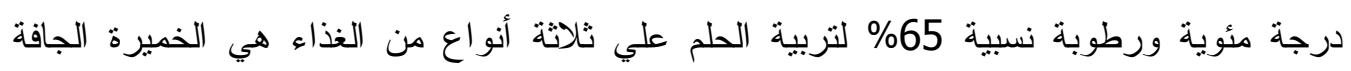

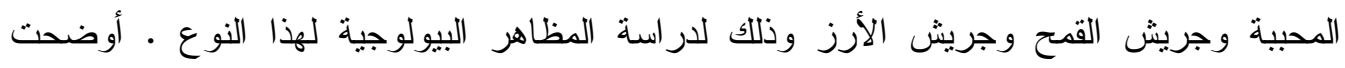

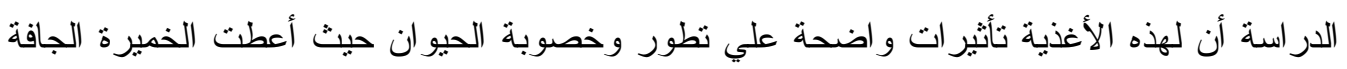
أعلي قيم معيشية لجداول الحياة بين الأغذية المختبرة. حيث أثنتت الدر اسة قدرة الحلم C. lactis علي التغذية و النطور علي الأغذية المختبرة ولقد استغرقت

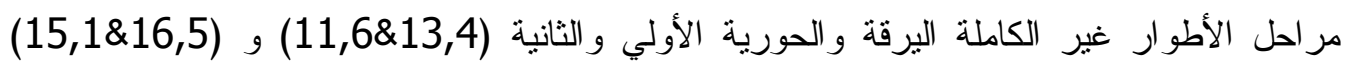

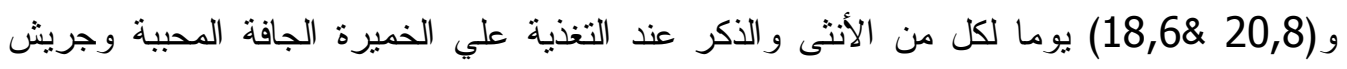

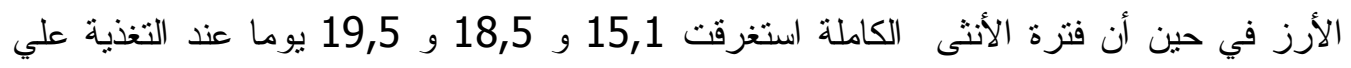

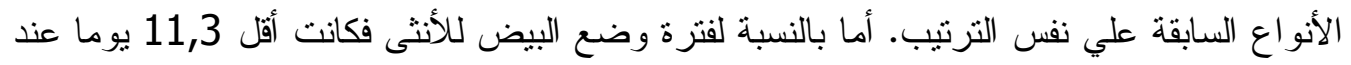

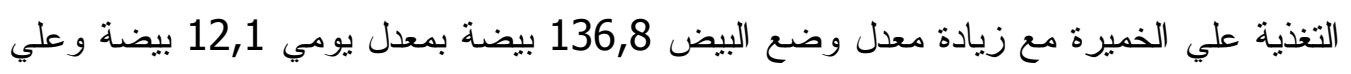

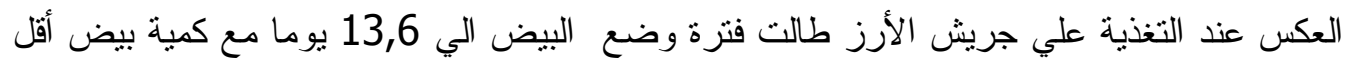

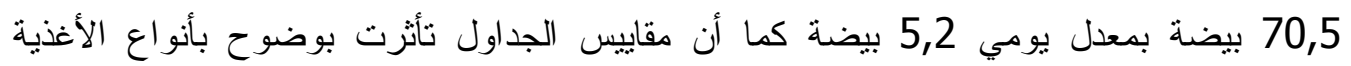
المختبرة من حيث متوسط فترة الجيل و المعدل الطبيعي للنمو و النسبة الجنسية ومعدل التكاثر . 
BIOLOGICAL STUDIES ON THE STORED GRAIN MITE, CARPOGLYPHUS LACTIS (LINNE) (ACARI:

ASTIGMATA:CARPOGLYPHIDAE) 